\title{
Assessment of the Water Quality of Bizerte Lagoon of Tunisia by Use of Statistical Analyses \\ Jamila $\mathbf{H}^{1^{*}}$, Mouldi $\mathbf{B}^{2}$ and Moncef $\mathbf{G}^{1}$
}

${ }^{1}$ Faculty of Sciences of Tunis, Department of Geology, University of Tunis El Manar, 1092 Tunis, Tunisia

${ }^{2}$ National Institute of Sea Sciences and Technologies, 28 Street of 2 March 1934, 2025 Salammbô, Tunisia

*Corresponding author: Hammami Jamila, Faculty of Sciences of Tunis, University of Tunis El Manar, 1092 Tunis, Tunisia, Tel: 0021696175643; E-mail: hammami.jamila@yahoo.fr

Rec date: Feb 19, 2016; Acc date: Apr 15, 2016; Pub date: Apr 22, 2016

Copyright: $\odot 2016$ Jamila $\mathrm{H}$, et al. This is an open-access article distributed under the terms of the Creative Commons Attribution License, which permits unrestricted use, distribution, and reproduction in any medium, provided the original author and source are credited.

\begin{abstract}
The purpose of this study is to provide a better understanding of the impact of different sources of stress (natural and human related) on water quality in a coastal lagoon (Bizerte, Tunisia). Impacts have been assessed through both surface and bottom water samples that were analysed for a range of chemical parameters. Results indicate that nutrient concentrations were generally high throughout the column especially during the rainy season. This period generally corresponds to intensive vertical mixing and massive discharge from rivers inflows. Concentrations were generally relatively high at the surface. The data structure is identified by the first three principal components explaining $68 \%$ of the total variance. Cluster analysis showed two different groups of similarity between the sampling sites reflecting the different physico-chemical characteristics and pollution levels of the studied water.
\end{abstract}

Keywords: Bizerte lagoon; Natural and human related; Nutrients; Principal component analysis; Cluster analysis

\section{Introduction}

In spite of the importance of wetlands for the ecological conservation of biodiversity, they are becoming threatened ecosystems around the world [1]. Many wetlands are disappearing as a consequence of human activities and thus they have been studied to enable their protection and preservation [2]. Indeed, maintaining good marine environmental quality is crucial for several socio-economic reasons [3]. Mediterranean lagoons are characterized by an anthropogenic catchement area, shallow depths, restricted exchange with the sea and by the variability of climatic forcing that they suffer from. Coastal lagoons, in many cases, are eutrophic or hypereutrophic environments because of high nutrient inputs from anthropogenic sources of autochthonous origin resulting high level of primary production [4]. Coastal lagoons with vulnerabilities, exhibit frequently a temporary and progressive decline of water quality. The increasing number of ecosystems with these symptoms led environmental managers to identify eutrophication as a major worldwide problem [5-7].

The environmental features of coastal lagoons (shallow water, strong seasonal temperature gradient, salinity, wind stress and tidal effects) result in high variability in short spatial and temporal scales of the communities [4]. In densely populated regions, the discharge of nitrogen and phosphorous is augmented by domestic and industrial waste waters, urban drainage and agricultural effluents [8-11].

In Tunisia, Bizerte lagoon has a great importance related to its contribution to the safeguard of the environment and the biodiversity and its socio-economic revenues in fishing and aquaculture. It is nowadays an area with severe environmental quality problems owing mainly to increased anthropogenic stresses, in the last decades, in and around the lagoon for the exploitation of the available natural resources. Factors contributing to this situation are: industrialization, urbanisation, domestic sewage and solid waste disposals, agriculture with fertilizer and agro-chemical apply tourism, oyster farming, and port activity. These achievements have badly affected the environment of the area in different manners, in particular water quality deterioration so as biodiversity and valuable biological resources degradation. Furthermore, because of the lack of respect of the environmental protection policy, the lagoon is becoming more and more eutrophised. Effluents are thrown out into the lagoon after treatment and/or without prior treatment causing severe consequences to both the ecosystem and the populations. Industrial effluents come from Bizerte, Zarzouna, Menzel Abderrahmn, Menzel Jemil and Menzel Bourguiba industrial complexes which consist of approximately 130 industries, including chemical, petrochemical, metallurgical, textile, agroalimentary production, cement production, fishing activities and which are subject to limited treatments.

The population living around the catchement area of Bizerte lagoon was about 273000 residents. Some urban agglomerations released the effluents untreated into rivers, especially the towns of Merazig and Guenniche, located respectively on the north-west and on the southeast. Other cities around the lagoon, Bizerte, Zarzouna, Menzel Jemil, Menzel Abderrahmen and Menzel Bourguiba towns have sewage systems but the treated wastewaters of the epuration stations (Bizerte and Menzel Bourguiba ones) outflow into the lagoon. In light of the above informations, the lagoon of Bizerte appear as a typical case of mixed influence from natural and anthropogenic nutrient enrichment. Numerous studies were carried out in the lagoon, but very little data about nutrients are available. It is therefore, the intention of this study to provide information on the characteristics and distributions of some descriptors of nutrients in surface and bottom waters. Physicochemical parameters (Temperature, salinity, $\mathrm{pH}$ and dissolved oxygen) were also measured to reveal their correlations between each other and with nutrients. 


\section{Description of the Study Area}

Bizerte lagoon is $13 \mathrm{~km}$ long, $11 \mathrm{~km}$ wide, with an area of 150000 hectares (Figure 1). The depression occupied by Bizerte lagoon corresponds to an ante-Neogene's massif collapsed and eroded from messinian [12]. The catchement area of consists of outcrops with a wide range of ages, from Eocene to Quaternary, and a variable lithology. The quaternary deposits are widely distributed on the surface. The villafranchien outcrops on the north of Lake Ichkeul and the Pleistocene occupy the plains and the low valleys [13]. Several tectonic events took place in the drainage area of Bizerte lagoon which was materialized by structure (anticlinal and synclinal axis) and fracture. On average, the water in Bizerte lagoon is $8 \mathrm{~m}$ deep, with the maximum depth of $12 \mathrm{~m}$ in the navigable channel, which cuts through the lagoon and allows the passage of large ships. The water progressively shallows shoreward [14]. This ecosystem is completely enclosed, except for the north, where it is open to the Mediterranean sea, and to the west, where it is linked to lake Ichkeul by of the Tinja River. It is fringed by small coastal basins to the north, by Mejerda low valley to the south, by catchement areas of the coastal region of Ras Jbel to the east and by lake Ichkeul to the west [15].

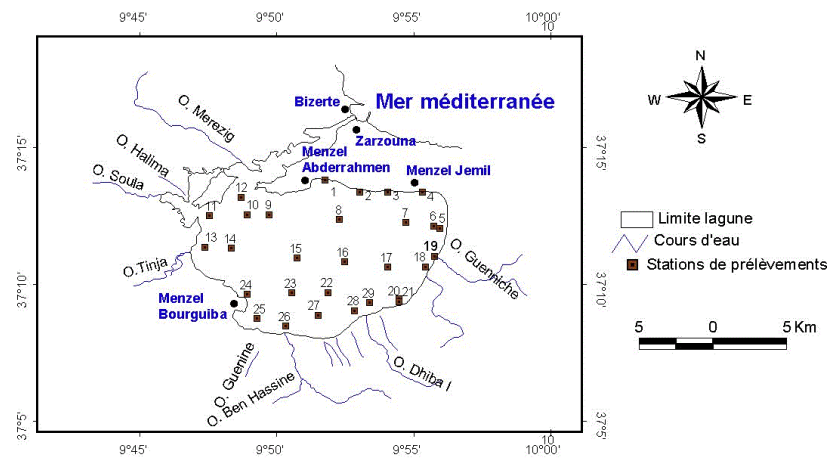

Figure 1: Location map of the study area and sampling points.

The region of Bizerte has a Mediterranean type climate with subhumid nuance. Summer is hot and dry and, in contrast, winter is mild and rainy. Rainfall is of downpour type and had an annual average of about 450 to $600 \mathrm{~mm}$ [16]. Bizerte lagoon constitutes a receiving basin of a hydrographic network which is constituted by fifteen streams. The streams of Merazig, Garek, Ben Hassine, Tinja and Guenniche represent the most important rivers which supply the lagoon with fresh water, especially during the rainy season [17].

\section{Sampling and Analysis}

\section{Data collection}

A total of 29 sampling points were chosen in Bizerte lagoon of Tunisia. The most of these points were subject to double collection: one sample just below the surface and the other near the bottom and this on two campaigns: the first on March 2003 and the second on June 2003.
The samples were taken during 2 days at each campaign. The geographical coordinates of lagoon sampling stations were determined by the use of a receiver of global positioning system (GPS radar). Water samples were collected by the use of a turning upside down bottle and stored in polyethylene bottles. The analytical parameters considered in this study are: Temperature, salinity, $\mathrm{pH}$, dissolved oxygen, ammonium $\left(\mathrm{NH}_{4}^{+}\right)$, nitrites $\left(\mathrm{NO}_{2}^{-}\right)$, nitrates $\left(\mathrm{NO}_{3}^{-}\right)$, organic nitrogen (Norg), kjeldhal nitrogen ( $\mathrm{Nkj}$ ), total nitrogen (TN), orthophosphates (Ortho$\mathrm{P}$ ), organic phosphorus (Porg) and total phosphorus (TP).

\section{Analysis methods}

Physico-chemical parameters were measured in situ after collection. Salinity and temperature were measured using a Microprocessor Conductivity Meter type LF 196; oxygen concentration using a Microprocessor oxymeter WTW Oxi 340 and $\mathrm{pH}$ was measured using a WTW 196T pH-meter. Nitrate, ammonia, nitrite, total phosphate phosphorus were measured using Merek Nova 60 Photometer. Kjeldhal nitrogen was measured by Mineralization of organic compounds of the sample and then dosage of ammonium with the bleu of indophenols' method. Orthophosphates was measured using the method of Murphy and Riley. Total nitrogen was measured as follow: Oxidation, in an autoclave and in the presence of an alcalinic solution of perulfate, of nitrogenic compounds to nitrates. $\mathrm{NO}_{3}{ }^{-}$was then reduced to $\mathrm{NO}_{2}{ }^{-}$ which was measured out in accordance with the sulphanilamide method.

The parameters thus measured are presented under form of thematic maps in a Geographical Information System. Statistical analysis of the experimental data has been performed utilising the Andad 7.1 software. Principal component analysis (PCA) attempts to find out associations between variables and reducing the dimensionality of the data matrix or correlation matrix. The loadings are evidence of the contribution of the original variables in the PCs. The eigen values of these last are a measure of their associated variance. For a further analysis of the data structure, Cluster Analysis (CA) was applied. The dataset was treated by the STATISTICA software (Statsoft Inc. ver. 6.0 for Windows). This approach aims at extracting the natural grouping of the samples [1]. In the Ward hierarchical clustering method, distance is given by the Euclidean equation. These methods are good tools for the identification of pollution source and correlation among constituents in the natural environment [17-20].

\section{Results and Discussions}

\section{General characteristics of data}

An initial discussion of the results is presented to provide a statement on water quality in the area of investigation. Descriptive statistics for the minimum and maximum concentrations for each variable at each period and depth of sampling are reported in Tables 1 and 2 .

\begin{tabular}{|l|l|l|l|l|l|l|l|}
\hline Variables & $\mathbf{n}$ & Minimum & Maximum & $\mathbf{n}$ & Minimum & Maximum \\
\hline & \multicolumn{3}{|l|}{ Surface waters } & \multicolumn{5}{|l|}{ Bottom waters } \\
\hline $\mathrm{T}^{\circ} \mathrm{C}$ & 29 & 13.2 & 17.7 & 22 & 13.9 & 16 \\
\hline Salinity & 29 & 19.1 & 30.2 & 22 & 29.3 & 34.5 \\
\hline O2 & 29 & 7.04 & 9.27 & 22 & 4.46 & 9 \\
\hline
\end{tabular}


Citation: Jamila H, Mouldi B, Moncef G (2016) Assessment of the Water Quality of Bizerte Lagoon of Tunisia by Use of Statistical Analyses. Hydrol Current Res 7: 237. doi:10.4172/2157-7587.1000237

Page 3 of 8

\begin{tabular}{|l|l|l|l|l|l|l|}
\hline $\mathrm{pH}$ & 29 & 6.88 & 9.6 & 22 & 7.56 & 9.5 \\
\hline NH4+ & 29 & 0.013 & 0.086 & 22 & 0.015 & 0.049 \\
\hline NO2- & 29 & 0.016 & 0.046 & 22 & 0.014 & 0.037 \\
\hline NO3- & 29 & 0.088 & 0.385 & 22 & 0.061 & 0.317 \\
\hline Nkj & 29 & 0.039 & 0.182 & 22 & 0.046 & 0.162 \\
\hline Norg & 29 & 0.012 & 0.138 & 22 & 0.024 & 0.113 \\
\hline TN & 29 & 0.163 & 0.404 & 22 & 0.186 & 0.3 \\
\hline Ortho-P & 29 & 0.033 & 0.071 & 22 & 0.033 & 0.073 \\
\hline TP & 29 & 0.08 & 0.112 & 22 & 0.08 & 0.108 \\
\hline Porg & 29 & 0.024 & 0.063 & 22 & 0.027 & 0.055 \\
\hline
\end{tabular}

Table 1: Summary statistics of the first survey (March: surface and bottom waters).

\begin{tabular}{|l|l|l|l|l|l|l|l|}
\hline Variables & $\mathbf{n}$ & Minimum & Maximum & $\mathbf{n}$ & Minimum & Maximum \\
\hline & \multicolumn{2}{|l|}{ Surface waters } & \multicolumn{3}{l|}{ Bottom waters } \\
\hline $\mathrm{T}^{\circ} \mathrm{C}$ & 26 & 26.3 & 28.7 & 22 & 25.8 & 27.1 \\
\hline Salinity & 26 & 27.3 & 34.8 & 22 & 34.3 & 34.9 \\
\hline O2 & 26 & 5.8 & 8.4 & 22 & 6 & 8.7 \\
\hline pH & 26 & 8.18 & 8.79 & 22 & 8.21 & 8.39 \\
\hline NH4+ & 26 & 0.001 & 0.024 & 22 & 0.001 & 0.019 \\
\hline NO2- & 26 & 0.005 & 0.034 & 22 & 0.007 & 0.019 \\
\hline NO3- & 26 & 0.002 & 0.096 & 22 & 0.024 & 0.11 \\
\hline Nkj & 26 & 0.023 & 0.082 & 22 & 0.028 & 0.067 \\
\hline Norg & 26 & 0.017 & 0.064 & 22 & 0.021 & 0.062 \\
\hline TN & 26 & 0.171 & 0.361 & 22 & 0.179 & 0.37 \\
\hline Ortho-P & 26 & 0.018 & 0.067 & 22 & 0.02 & 0.057 \\
\hline TP & 26 & 0.08 & 0.107 & 22 & 0.08 & 0.112 \\
\hline Porg & 26 & 0.028 & 0.073 & 22 & 0.024 & 0.078 \\
\hline
\end{tabular}

Table 2: Summary statistics of the second survey (June: surface and bottom waters).

Physico-chemical parameters: Some physico-chemical (temperature and salinity) undergo wide seasonal variations. Temperature minima during the wet period were as low as $15.52 \mathrm{C}$ in surface waters and $14.91^{\circ} \mathrm{C}$ in bottom waters, and dry period maxima reached $27.04^{\circ} \mathrm{C}$ and $26.43^{\circ} \mathrm{C}$ respectively on the surface and near the bottom. Temperature is a key factor influencing the benthic fluxes of nutrients and promotes a temporal variability in sediment-water nutrient exchanges in coastal environments with marked seasons [21-25].

Surface waters were a few low in salinity. Salinity of the surface waters ranged between 19.1 and $30.2 \mathrm{~g} / \mathrm{l}$ (March) and between 27.3 and $34.8 \mathrm{~g} / \mathrm{l}$ (June). Bottom waters had salinity varying between 29.3 and $34.5 \mathrm{~g} / \mathrm{l}$ (March) and between 34.3 and $34.9 \mathrm{~g} / \mathrm{l}$ (June). The lowest salinities were present in station 13 corresponding of the outlet of

Tinja's river (19.1 and 27.3 in surface waters on March and June 2003 respectively).

A progressive temperature increase at the surface and bottom waters was observed along a north to south gradient, in March 2003 and from the east towards the west in June (Figures 2 and 3). These gradients were caused by the dominant influence of Mediterranean waters on the north, the effect of exchange of water between lake Ichkeul and Bizerte lagoon on the west and, the direct influence of the air temperature related with the thickness of the water slice. In fact, the east-west gradient observed during the dry season campaign was caused by the fact that water in lake Ichkeul is more affected by solar radiation, mainly due to the water being shallower ( $1 \mathrm{~m}$ deep of average).

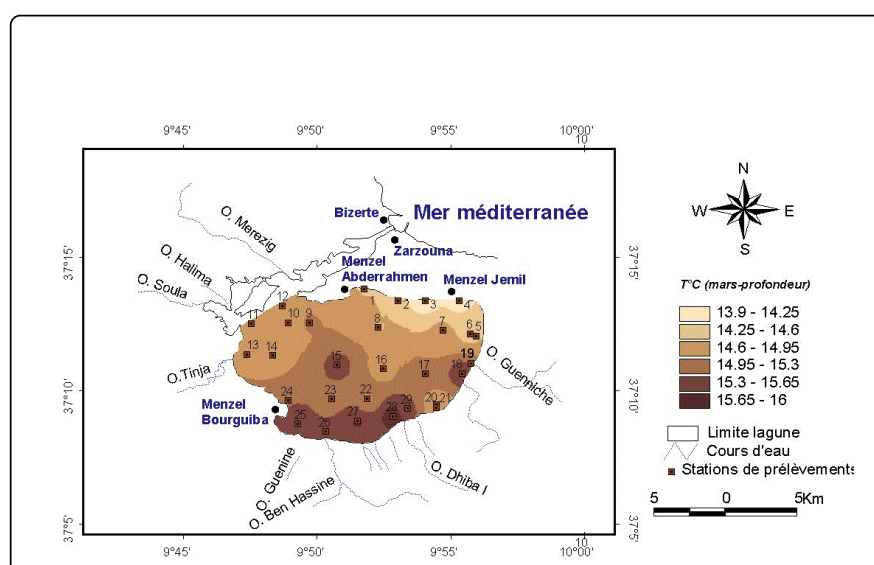

Figure 2: Distribution of temperature during the first field survey (bottom waters).

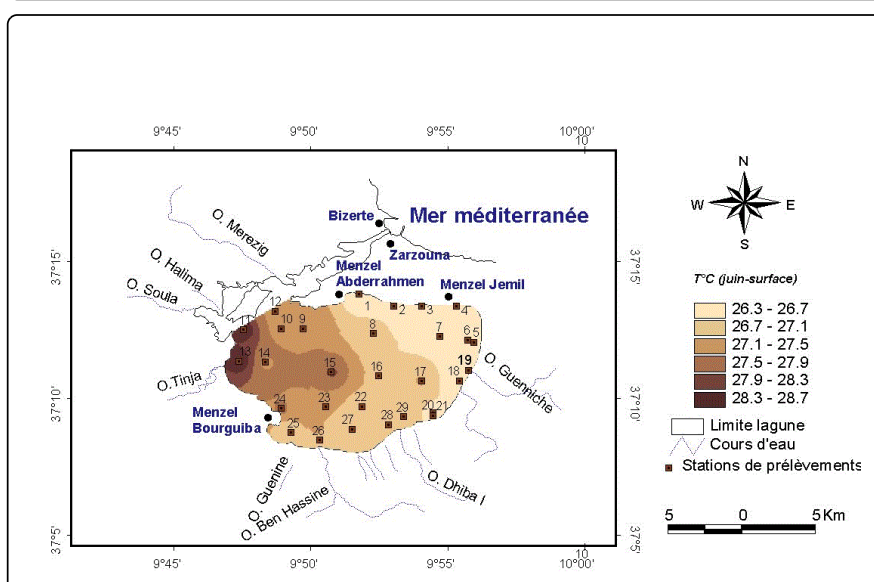

Figure 3: Distribution of temperature during the second field survey (surface waters).

Salinity in the study area of the lagoon showed, on the whole, horizontal uniformity. A greater influence from fresh waters was observed in the west sector corresponding of the entrance of lake Ichkeul fresh waters towards river of Tinja and thus where the impact of dilution is rather high (Figures 4 and 5). On the whole, the space evolution of salinity in Bizerte lagoon of Tunisia reflect different degrees of fresh and marine waters influence and were, also under the 
influence of climatic conditions. Higher values in summer could be attributed to the restricted entry of freshwater and higher resident time of saline water in the shallow lagoon system during summer [4].

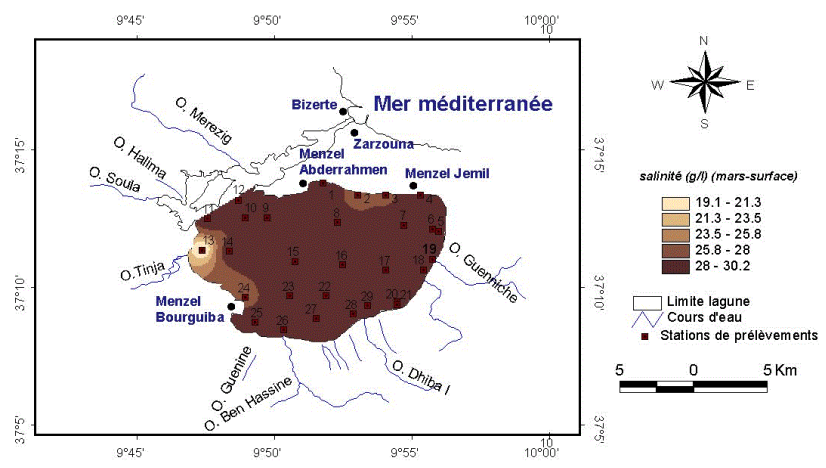

Figure 4: Distribution of salinity during the first field survey (surface waters).

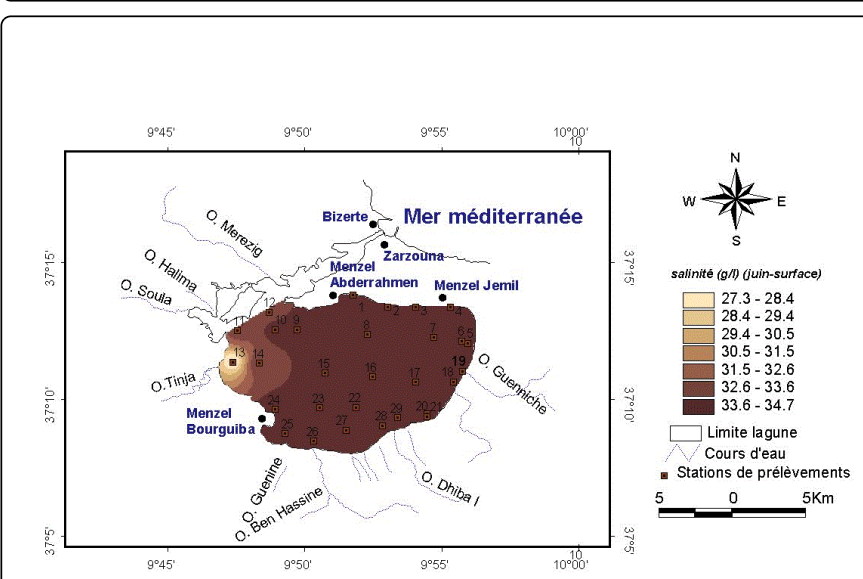

Figure 5: Distribution of salinity during the second field survey (surface waters).

The range of dissolved oxygen in different sectors shows that the lagoon water is well saturated. Dissolved oxygen content in surface waters were, generally, slightly high on March 2003 (7.04-9.27 mg.l-1) relative to that on June 2003 (5.8-8.4 mg. $\left.\mathrm{l}^{-1}\right)$. Dissolved oxygen in aquatic ecosystems is the function of many physicochemical parameters, which govern their solubility. The important biological processes associated with oxygen distribution are photosynthesis, respiration and decomposition [26].

On March 2003, pH of Bizerte lagoon has a medium value of 8.34 in surface water and 8.62 on bottom water. On June 2003, the median values of this parameter were 8.30 on the surface and 8.29 near the bottom samples.

Nutrients: The higher concentrations of nutrients, except for organic phosphorus, were measured on March 2003 (first survey). This period generally corresponds to intensive vertical mixing and massive discharge from rivers inflows. Concentrations were generally relatively high at the surface. The total concentrations of $\mathrm{NH}_{4}{ }^{+}$and $\mathrm{NO}_{2}{ }^{-}$were relatively low in all stations. Low values were a result of rapid mobilisation. In fact, these elements are transitory and are not stable, in waters having very weak dissolved oxygen concentrations [27]. For this reason, their concentrations in the water column cannot be high. Ammonium may differ from steady-state conditions reflecting the balance between production through organic matter mineralization [28], nitrification/denitrification and consumption by the abundant primary producers living near the sediment-water interface [25].

Ammonium in surface waters samples had media concentrations (as mg. $\mathrm{l}^{-1}$ ) of 0.030 (March 2003) and 0.006 (June 2003) for the whole data matrix. Samples collected at depth had median values of $0.026 \mathrm{mg} . \mathrm{l}^{-1}$ and $0.006 \mathrm{mg} . \mathrm{l}^{-1}$, respectively on March and June 2003.

Dissolved inorganic nitrogen (DIN) was mainly found as nitrates that had the greatest mean concentration in the data set, as shown in tables of summary statistics, with a range of values between 0.088 and 0.385 mg..$^{-1}$ in surface samples collected on March 2003 and between 0.061 and $0.317 \mathrm{mg}^{-1} \mathrm{l}^{-1}$ in bottom ones. Samples collected on the second survey (June 2003) had a range of values between 0.002 and $0.096 \mathrm{mg} . \mathrm{l}^{-1}$ and between 0.024 and $0.110 \mathrm{mg} . \mathrm{l}^{-1}$, respectively on the surface and bottom waters. Nitrification/denitrification processes are also temperature-dependent. Thus, during the period of higher temperature (maximum of $25^{\circ} \mathrm{C}$ ), denitrification of nitrate to the gaseous forms of nitrogen $\mathrm{N}_{2}$ and $\mathrm{N}_{2} \mathrm{O}$ may contribute to drop nitrate levels [11,29].

On March 2003, the spatial distribution of nitrates reveals some heterogeneity between surface and bottom waters. On June 2003, high concentrations of $\mathrm{NO}_{3}^{-}(0.049-0.096 \mathrm{mg} / \mathrm{l}$ on the surface and $0.049-0.110 \mathrm{mg} / \mathrm{l}$ on the bottom) were found mainly on the north, near the towns of Menzel Jemil and Menzel Abderrahmen and on the south-west, from Menzel Bourguiba until the outlet of Dhiba river. Nitrates detected in Bizerte lagoon waters had, in addition to the natural origin, an anthropogenic source. In fact, the flow of liquid rejections into Bizerte lagoon were of $52087 \mathrm{~m}^{3} /$ day, $19996 \mathrm{~m}^{3} /$ day (38.5\%) of which correspond to urban wastewater and $31886 \mathrm{~m}^{3} /$ day $(61 \%)$ to industrial wastewater. These effluents bring $61.2 \mathrm{~kg} / \mathrm{day}$ of nitrates.

Total nitrogen display little variation in elemental concentration between the two periods of field surveys (March and June 2003) and between surface and near bottom waters, especially on June. Media values of the first field survey were of $0.265 \mathrm{mg}^{-1}{ }^{-1}$ for surface samples and of $0.244 \mathrm{mg} . \mathrm{l}^{-1}$ for bottom ones. Those of the second survey were of $0.235 \mathrm{mg} . \mathrm{l}^{-1}$ and $0.237 \mathrm{mg} . \mathrm{l}^{-1}$, respectively. Phosphorus is one of the essential elements maintaining primary production but with an excess loading having undesirable consequences, such as eutrophication, for coastal marine ecosystems. Orthophosphates, organic phosphorus and total phosphorus in surface water samples have mean concentrations in the data set, as shown in the summary statistics tables, of 0.052 , 0.040 and $0.094 \mathrm{mg} .1^{-1}$, respectively, for the first campaign and of 0.041 , 0.052 and $0.095 \mathrm{mg} . \mathrm{l}^{-1}$, respectively, for the second campaign.

Median values corresponding to bottom water samples collected on March 2003, were $0.055 \mathrm{mg} . \mathrm{l}^{-1}$ for Ortho-P $0.042 \mathrm{mg} . \mathrm{l}^{-1}$ for organic phosphorus and $0.096 \mathrm{mg}^{-1}$ for total phosphorus. Those of June 2003 samples were $0.046 \mathrm{mg} . \mathrm{l}^{-1}, 0.049 \mathrm{mg} . \mathrm{l}^{-1}$ and $0.092 \mathrm{mg} . \mathrm{l}^{-1}$, respectively.

Phosphate concentrations were positively correlated with temperature in summer, indicating the release of phosphate from sediments of the inner areas of the lagoon [11], but we suggest 
Page 5 of 8

influences of other variables besides temperature as dissolved oxygen as referred in several studies [30,31]. Variations can also be caused by various processes like adsorption and desorption of phosphate and buffering action of sediment under varying environmental condition [32]. Ortho-P is the most biologically available form of $\mathrm{P}$ for aquatic microorganisms. The waters of Bizerte lagoon were, on the whole, neuter to thoughtlessly alkaline. Orthophosphates were so present, essentially, under form of $\mathrm{HPO}_{4}{ }^{2-}$ ion. The loads of this element showed very heterogenic spatial distribution.

The concentration and distribution of organic phosphorus is quite different in the surface and the bottom water of the basin. It is related to the inputs of waters rich in organic phosphorus by rivers draining the catchment area of the lagoon, as well as, to urban effluents. Concentrations of total phosphorus did not show an obvious evolutive spatio-temporal trend. Nevertheless, the measured concentrations of total phosphorus can be explained, principally, by an anthropogenic source. In fact, the input of total phosphorus by the liquid effluents thrown into Bizerte lagoon are of about $38.6 \mathrm{~kg} / \mathrm{day}$ : $76 \%$ from industrial rejections and $24 \%$ from domestic wastewater. Primary production by phytoplankton in a water body depends upon the relative availability of nitrogen and phosphorous. In coastal lagoons the N: P ratio usually remains lower than the normal Redfield's ratio (16:1), because biological removal of nitrogen relative to its availability is higher than that of the phosphorous. But, reverse situation resulting in high $\mathrm{N}: \mathrm{P}$ ratio was also observed, due to high rate of nitrogen input through freshwater [4].

\section{Statistical analysis and discussions}

Various environmetric statistical approaches are frequently employed for the assessment of the water quality and the marine environment [33-37]. As noted by Massart [33], multivariate statistical methods reduce the dimensionality of the data and extract information that will be helpful for the water quality assessment and the management of surface waters. For this purpose, we applied PCA and $\mathrm{CA}$ to the original data obtained during the two field surveys (March and June 2003) in Bizerte lagoon of Tunisia. Multivariate statistical analysis described in this paper, were applied on 13 variables, 9 nutrients $\left(\mathrm{NH}_{4}{ }^{+}, \mathrm{NO}_{2}{ }^{-}, \mathrm{NO}_{3}{ }^{-}\right.$, Norg, Nkj, TN, Ortho-P, Porg, $\left.\mathrm{TP}\right)$ and 4 physico-chemical parameters (Temperature, salinity, $\mathrm{pH}$ and dissolved oxygen) in 29 sampling sites.

Correlations between variables: Correlations between variables are statistically tested and show high values among some parameters. In Table 3 the Pearson's correlation coefficient ( $r$ ) matrix for the sampled is presented. Correlations indices range from $r=0.410$ to $r=0.898$. These results indicate that such elements have similar trends. High and positive correlations were observed: ammonium and nitrites $(\mathrm{r}=0.594)$, ammonium and nitrates ( $\mathrm{r}=0.680$ ), ammonium and kjeldhal nitrogen $(\mathrm{r}=0.731)$, nitrites and nitrates $(\mathrm{r}=0.686)$, nitrites and kjeldhal nitrogen $(\mathrm{r}=0.547)$, nitrates and kjeldhal nitrogen $(\mathrm{r}=0.610)$, kjeldhal nitrogen and organic nitrogen $(\mathrm{r}=0.898)$. By contrast, $\mathrm{pH}$ has very weak correlation with all variables. The high correlations between the elements given above indicate that they have similar anthropogenic sources.

\begin{tabular}{|c|c|c|c|c|c|c|c|c|c|c|c|c|c|}
\hline & $\mathrm{T}^{\circ} \mathrm{C}$ & Sali & $\mathbf{O}_{2}$ & $\mathrm{pH}$ & $\mathrm{NH}_{4}{ }^{+}$ & $\mathrm{NO}_{2}^{-}$ & $\mathrm{NO}_{3}^{-}$ & Nkj & Norg & TN & Orth & TP & Porg \\
\hline $\mathrm{T}^{\circ} \mathrm{C}$ & 1 & & & & & & & & & & & & \\
\hline Sali & 0.763 & 1 & & & & & & & & & & & \\
\hline $\mathrm{O}_{2}$ & -0.452 & -0.57 & 1 & & & & & & & & & & \\
\hline $\mathrm{pH}$ & -0.113 & -0.07 & -0.085 & 1 & & & & & & & & & \\
\hline $\mathrm{NH}_{4}^{+}$ & -0.741 & -0.62 & 0.353 & 0.081 & 1 & & & & & & & & \\
\hline $\mathrm{NO}_{2}^{-}$ & -0.793 & -0.67 & 0.358 & 0.168 & 0.594 & 1 & & & & & & & \\
\hline $\mathrm{NO}_{3}^{-}$ & -0.787 & -0.76 & 0.324 & 0.248 & 0.68 & 0.686 & 1 & & & & & & \\
\hline Nkj & -0.687 & -0.54 & 0.365 & -0.157 & 0.731 & 0.547 & 0.61 & 1 & & & & & \\
\hline Norg & -0.463 & -0.34 & 0.272 & -0.268 & 0.357 & 0.367 & 0.397 & 0.898 & 1 & & & & \\
\hline TN & -0.227 & -0.25 & 0.262 & -0.193 & 0.487 & 0.393 & 0.289 & 0.443 & 0.294 & 1 & & & \\
\hline Orth & -0.482 & -0.43 & 0.452 & 0.018 & 0.429 & 0.397 & 0.417 & 0.455 & 0.347 & 0.279 & 1 & & \\
\hline $\mathrm{Tp}$ & -0.11 & -0.09 & 0.029 & 0.011 & 0.149 & 0.128 & 0.145 & 0.052 & -0.024 & 0.252 & 0.323 & 1 & \\
\hline Porg & 0.41 & 0.366 & -0.433 & -0.011 & -0.332 & -0.314 & -0.32 & -0.421 & -0.363 & -0.12 & -0.789 & 0.325 & 1 \\
\hline
\end{tabular}

Table 3: Correlation matrix showing relationships among the analysed variables.

Principal component analysis: A principal components analysis (PCA) was carried out. This mathematical method was applied in order to obtain an integrated view on the relationships within a set of variables or objects. The analysis generated seven principal components with eigen values $>1$ summing almost $92.52 \%$ of the total variance in the water dataset. The first three components explained
$68.24 \%$ of the total variance and could be considered as representative for describing the factor model of the lagoon water chemistry.

Most of the variance is contained in the first PC (45.29\% of the total variance). This PC was highly weighted due to the contribution of temperature, salinity, dissolved oxygen, ammonium, nitrites, kjeldhal nitrogen, organic nitrogen, total nitrogen, orthophosphates and organic phosphorus (Figure 6). Temperature, salinity and Porg had 
Page 6 of 8

positive sign, the rest of variables had negative sign and most of them had larger weight in the first three principal components, indicating that none of them should be neglected. The variables, plotted in the plane defined by the first two principal components, appear separated into distinct groups. Group 1 composed by $\mathrm{T}^{\circ} \mathrm{C}$, salinity and Porg is characterised by high values of the scores on PC1 while group 2, composed by $\mathrm{NO}_{3}{ }^{-}, \mathrm{NO}_{2}{ }^{-}, \mathrm{NH}_{4}{ }^{+}$, Ortho- $\mathrm{P}, \mathrm{O}_{2}, \mathrm{TN}, \mathrm{Nkj}$ and Norg, lies in the opposite direction. $\mathrm{pH}$ is characterised by high values for component 2 and low values for component 1 . Total phosphorus seems to be independent from the other variables.

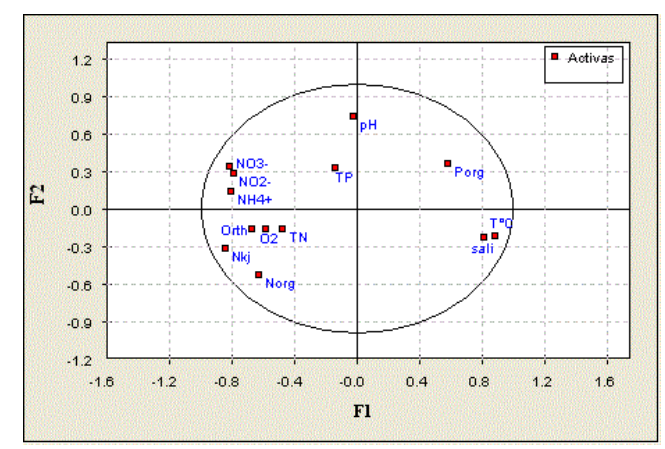

Figure 6: Projection of variables in the space axes (F1, F2).

The analysed samples, that have been differentiated according to surveys ( $\mathrm{M}=\mathrm{March}$ and $\mathrm{J}=\mathrm{June}$ ) and locations ( $\mathrm{S}=$ Surface and $\mathrm{B}=$ bottom), are plotted in a plane diagram, using the first two PCs. Separation of samples in two main groups is observed (Figure 7). The samples corresponding to the second survey (June) and to both surface and bottom sampling (JS and JB) are compactly clustered at the positive side of $\mathrm{PC} 1$. The samples corresponding to the second survey (March) are dispersed in the space of the negative side of PC1.

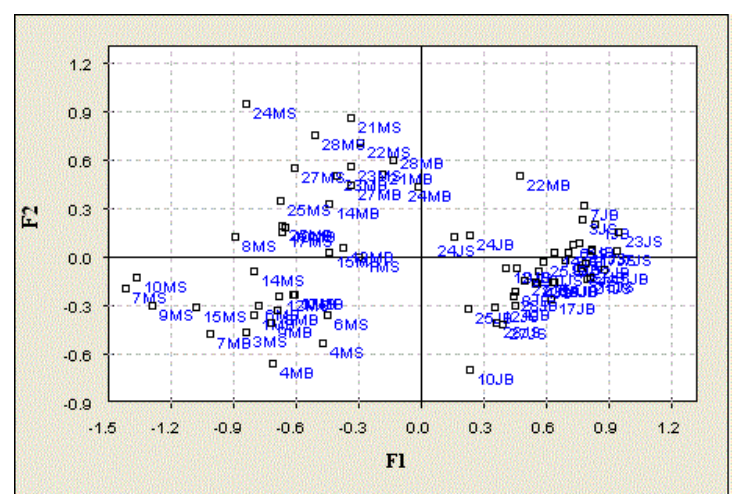

Figure 7: Projection of the samples in the plane defined by the first two principal components (F1, F2).

Taking into account the negative loadings of PC1 (exception made for temperature, salinity and organic phosphorus) we can deduce that samples collected on March 2003 had in general higher nutrient and dissolved oxygen content while samples of June 2003 showed a marked lower nutrient and dissolved oxygen enrichment. Thus, PC1 seems to differentiate between surveys, without dependence on the sampling depth, and this on the basis of different degree of nutrient enrichment.
Cluster analysis: In clustering the samples are grouped so that similar samples or stations fall into the same class. In the cluster analysis applied to our data, the Ward hierarchical clustering method using Euclidean distance was performed. The mean values of nutrients and physico-chemical parameters at each station were used.

The dendrogram shows two statistically significant clusters (Figure 8). Cluster 1 corresponds to the sampling sites $1,3,4,6,7,8,9,10,12$ and 14 and cluster 2 to the following ones: 15, 21, 23, 17, 22, 24, 25, 27 and 28 . Group 2 comprises samples having more degree of similarity rather than group 1 .

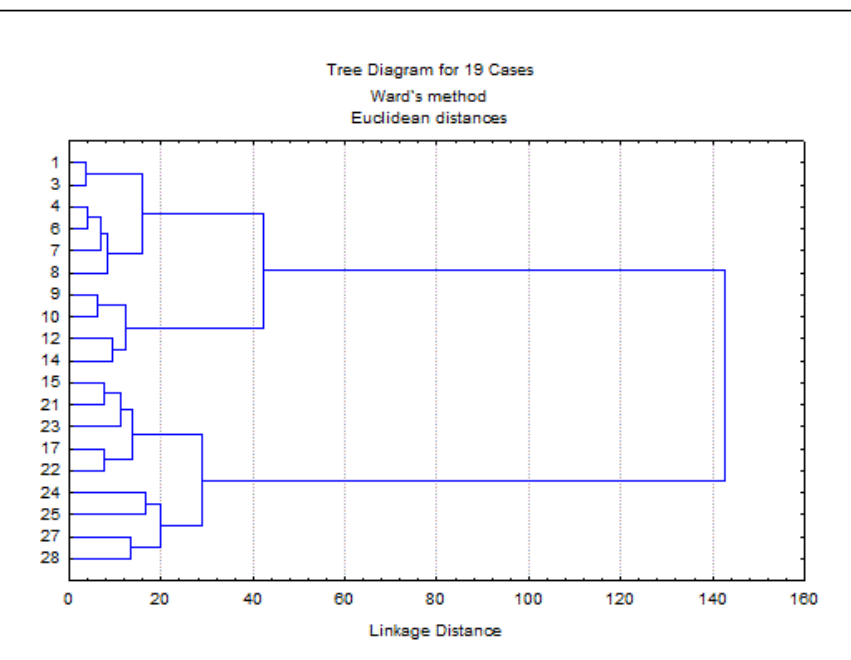

Figure 8: Cluster analysis (the horizontal axis indicates the similarity of different cluster groups: lesser is the distance, greater is the similarity between objects).

Samples of group 1 are located on the north part of the lagoon and have an influence from marine water catching the lagoon through the channel, from the Tinja's river input and from the rejections of Menzel Abderrahmen and Menzel Jemil towns. On the contrary, group 2 comprises of samples located on the middle and the south part of the lagoon and that may be influenced by effluents from the town of Menzel Bourguiba and by the hydrographic network inputs.

\section{Conclusions}

Field and laboratory investigation undertaken in surface and bottom water chemistry of Bizerte lagoon during two field surveys (March and June 2003) on 29 key sampling sites showed that nutrient concentrations were generally higher throughout the column during the first survey (March 2003), with the exception of organic phosphorus. They are interpreted to be natural in origin, rather than the result of pollution by manmade activities. Anthropogenic contributions were apparent, indicating the influences of point (municipal and industrial effluents) and non-point sources (agricultural runoff). The DIN content is higher than the Ortho-P concentration. Ortho-P might be limiting for phytoplankton growth.

Three PCs having eigenvalues greater than unity were extracted ( $68 \%$ of the variance). The most interesting result from the PC1/PC2 plot is the separation of sampling time along PC1 that show that most of the variance can be explained by three factors: the thermal regime, nutrient loading and the carbon cycle, as represented by $\mathrm{pH}$ variations. It should be noted however that $\mathrm{pH}$ values are seldom acidic, given the 
buffering capacity of salt water. Cluster analysis reveals two main groups of stations including sampling sites with similar characteristics features. Group 1, located on the north part of the lagoon, seems to be influenced by mediterranean water, the Tinja's river water and by the effluents of the towns of Menzel Abderrahmen and Menzel Jemil. The sampling sites of group 2, located on the middle and the southern part of the lagoon, may be subjected to the sewage effluents from the town of Menzel Bourguiba and to freshwater inflows of the hydrographic network.

\section{References}

1. Berzas JJ, Garcia LF, Rodríguez RC, Alvarez M (2000) Evolution of the water quality of a managed natural wetland: Tablas De Daimiel National Park (Spain). Water Research 34: 3161-3170.

2. Puigserver M, Ramon G, Moya G (2002) Spatial and temporal distribution of phytoplankton in a Mediterranean estuarine canal system. Journal of coastal research 18: 39-51.

3. De Mora S, Fowler SW, Wyse E, Azemard S (2004) Distribution of heavy metals in marine bivalves, fish and coastal sediments in the Gulf and Gulf of Oman. Marine Pollution Bulletin 49: 410-424.

4. Panigrahi S, Achraya BC, Panigrahi RC, Nayak BK, Banarjee K, et al. (2007) Anthropogenic impact on water quality of Chilika lagoon RAMSAR site: a statistical approach. Wetlands Ecological Management 15: 113-126.

5. Cloern JE (2001) Our evolving conceptual model of coastal eutrophication problem. Marine Ecology Progress Series 210: 223-253.

6. Hauxwell J, Valiela I (2004) Effects of nutrient loading on shallow seagrass-dominated coastal systems: Patterns and processes. In: Nielsen SL, Banta GT, Pedersen MF (eds). Estuarine Nutrient Cycling: The influence of primary producers, London: Kluwer, pp: 59-92.

7. Lillebø AI, Teixeira H, Pardal MA, Marques JC (2007) Applying quality status criteria to a temperate estuary before and after the mitigation measures to reduce eutrophication symptoms. Estuarine, Coastal and Shelf Science 72: 177-187.

8. Cabeçadas G, Nogueira M, Brogueira MJ (1999) Nutrient dynamics and productivity in three European estuaries. Marine Pollution Bulletin 38: 1092-1096.

9. Lillebø AI, Neto JM, Martins I, Verdelhos T, Leston S, et al. (2005) Management of a shallow temperate estuary to control eutrophication: the effect of hydrodynamics on the system nutrient loading. Estuarine, Coastal and Shelf Science 65: 697-707.

10. Lopes CB, Lillebø AI, Dias JM, Pereira E, Vale C, et al. (2007) Nutrient dynamics and seasonal succession of phytoplankton assemblages in a Southern European Estuary: Ria de Aveiro, Portugal. Estuarine, Coastal and Shelf Science 71: 480-490.

11. Pereira P, Pablo DH, Vale C, Franco V, Nogueira M (2009) Spatial and seasonal variation of water quality in an impacted coastal lagoon (Obidos Lagoon, Portugal). Environmental Monitoring and Assessment 153: 281-292.

12. Masri A (1996) Study of the impact of sediment dynamics on the stability of the coast on the Bay of Bizerte. DEA, Tunis, p: 130.

13. Mathlouthi S (1985) Geomorphological study of the area of the lake system of Bizerte. 3rd cycle thesis, Faculty of Humanities and Social Sciences of Tunis, p: 206.

14. Soussi N (1981) Mechanisms of sedimentation and paleogeographic evolution of the lagoon of Bizerte (Tunisia) during the recent Quaternary. PhD Thesis, University of Toulouse, p: 200.

15. Kallel MR (1989) Hydrologie du lac de Bizerte. Rapport Interne, DGRE, Tunis, p: 15.

16. Mansouri T (1996) Application of remote sensing and geographic information systems in the study of the hydrological functioning of Lake Bizerte and its watershed. DEA, p: 140.
17. Ashley JTF, Baker JE (1999) Hydrophobic organic contaminants in surficial sediments of Baltimore Harbor: Inventories and sources. Environmental Toxicology and Chemistry 18: 838-849.

18. Loska K, Wiechula D (2003) Application of principal component analysis for the estimation of sources of heavy metal contamination in surface sediments from the Rybnik Reservoir. Chemosphere 51: 723-733.

19. Kazi TG, Arain MB, Jamali MK, Jalbani N, Afridi HI (2009) Assessment of water quality of polluted lake using multivariate statistical techniques: A case study. Ecotoxicology and Environmental Safety 72: 301-309.

20. Karroubi A, Gargouri D, Baati H, Azri C (2012) Assessment of sediment quality in the Mediterranean Sea-Boughrara lagoon exchange areas (southeastern Tunisia): GIS approach-based chemometric methods. Environmental Monitoring and Assessment 184: 4001-4014.

21. Van Raaphorst W, Kloosterhuis HT, Berghuis EM, Gieles AJM, Malschaert JFP et al. (1992) Nitrogen cycling in two types of sediments of the southern north sea (frisian frint, broad fourteens): Field data and mesocosm results. Netherlands Journal of Sea Research 28: 293-316.

22. Kristensen E (1993) Seasonal variations in benthic community metabolism and nitrogen dynamics in a shallow, organic-poor Danish lagoon. Estuarine, Coastal and Shelf Science 36: 565-586.

23. Wilson JG, Brennan MT (2004) Spatial and temporal variability in modeled nutrient fluxes from the unpolluted Shannon estuary, Ireland, and the implications from microphytobenthic productivity. Estuarine, Coastal and Shelf Science 60: 193-201.

24. Forja JM, Blasco J, Gómez Parra A (1994) Spatial and seasonal variation of in situ benthic fluxes in the Bay of Cadiz (south-west Spain). Estuarine, Coastal and Shelf Science 39: 127-141.

25. Vidal M, Morguí JA (1995) Short-term pore water ammonium variability coupled to benthic boundary layer dynamics in Alfacs bay, Spain (Ebro Delta, NW Mediterranean). Marine Ecology Progress Series 118: 229-236.

26. Aston SR (1980) Nutrients, dissolved gases and general biogeochemistry in estuaries. In: Olausson E, Cato I (eds.). Chemistry and biogeochemistry of estuaries, John Wiley and Sons, New York, pp: 233-262.

27. Copin Montégut G (1996) Chemistry of seawater Oceanographic Institute. Paris, p: 302.

28. Bally G, Mesnage V, Deloffre J, Clarisse O, Lafite R, et al. (2004) Chemical characterization of porewaters in an intertidal mudflat of the Seine estuary: Relationship to erosion-deposition cycles. Marine Pollution Bulletin 49: 163-173.

29. Cartaxana P, Caçador I, Vale C, Falcão M, Catarino F (1999) Seasonal variation of inorganic nitrogen and net mineralization in a salt marsh ecosystem. Mangroves Salt Marsh 3: 127-134.

30. Slomp CP, Malschaert JF, Van Raaphorst W (1998) The role of absorption in sediment-water exchange of phosphate in North Sea continental margin. Limnology and Oceanography 43: 832-846.

31. Asmus RM, Sprung M, Asmus H (2000) Nutrient fluxes in intertidal communities of a south European lagoon (RiaFormosa)-similarities and differences with a northern Wadden Sea bay. Hydrobiologia 436: 217-235.

32. Pomeroy CR, Smith EE, Grant CM (1965) The exchange of phosphate between estuarine water and sediments. Limnology Oceanography 10: 167-172.

33. Simeonov V, Stratis JA, Samara C, Zachariadis G, Voutsa D, et al. (2003) Assessment of the surface water quality in Northern Greece. Water Research 37: 4119-4124.

34. Helena B, Pardo R, Vega M, Barrado E, Fernandez JM, et al. (2000) Temporal evolution of groundwater composition in an alluvial aquifer (Pisuerga River, Spain) by principal component analysis. Water Research 34: 807-816.

35. Pekey H, Karakas D, Bakoglu M (2004) Source apportionment of trace metals in surface waters of a polluted stream using multivariate statistical analyses. Marine Pollution Bulletin, 49: 809-818.

36. Romano E, Ausili A, Zharova N, Magno MC, Pavoni B et al. (2004) Marine sediment contamination of an industrial site at Port of Bagnoli, Gulf of Naples, Southern Italy. Marine Pollution Bulletin 49: 487-495. 
Citation: Jamila H, Mouldi B, Moncef G (2016) Assessment of the Water Quality of Bizerte Lagoon of Tunisia by Use of Statistical Analyses. Hydrol Current Res 7: 237. doi:10.4172/2157-7587.1000237

Page 8 of 8

37. Arhonditsis G, Karydis M, Tsirtsis G (2002) Integration of mathematical modelling and multicriteria methods in assessing environmental change in developing areas: a case study of a coastal system. Journal of coastal research 18: 698-711. 